\title{
Case Studies from the Climate Technology Partnership: Landfill Gas Projects in South Korea and Lessons Learned
}

C. Larney

National Renewable Energy Laboratory

M. Heil

U.S. EPA

G.-A. Ha

Korea Energy Management Company

Technical Report NREL/TP-710-40428

December 2006

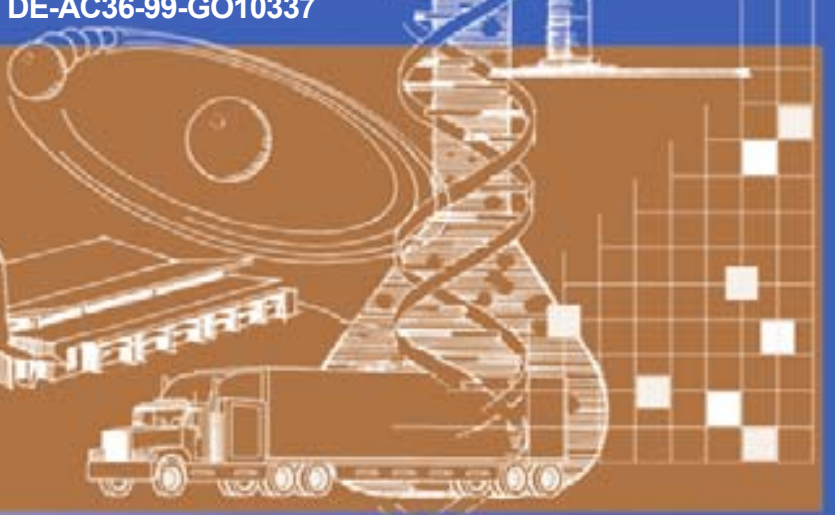




\section{Case Studies from the Climate Technology Partnership: Landfill Gas Projects in South Korea and Lessons Learned}

C. Larney

National Renewable Energy Laboratory

M. Heil

U.S. EPA

G.-A. Ha

Korea Energy Management Company

Prepared under Task No. WF98.2010

National Renewable Energy Laboratory

1617 Cole Boulevard, Golden, Colorado 80401-3393

303-275-3000 • www.nrel.gov

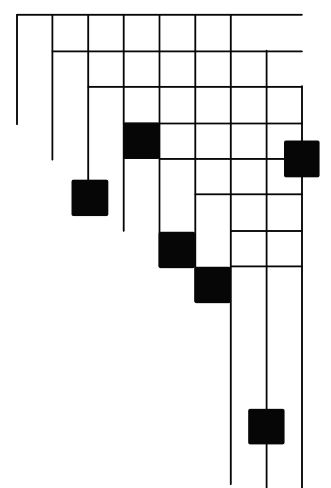




\section{NOTICE}

This report was prepared as an account of work sponsored by an agency of the United States government. Neither the United States government nor any agency thereof, nor any of their employees, makes any warranty, express or implied, or assumes any legal liability or responsibility for the accuracy, completeness, or usefulness of any information, apparatus, product, or process disclosed, or represents that its use would not infringe privately owned rights. Reference herein to any specific commercial product, process, or service by trade name, trademark, manufacturer, or otherwise does not necessarily constitute or imply its endorsement, recommendation, or favoring by the United States government or any agency thereof. The views and opinions of authors expressed herein do not necessarily state or reflect those of the United States government or any agency thereof.

Available electronically at http://www.osti.gov/bridge

Available for a processing fee to U.S. Department of Energy and its contractors, in paper, from:

U.S. Department of Energy

Office of Scientific and Technical Information

P.O. Box 62

Oak Ridge, TN 37831-0062

phone: 865.576 .8401

fax: 865.576 .5728

email: mailto:reports@adonis.osti.gov

Available for sale to the public, in paper, from:

U.S. Department of Commerce

National Technical Information Service

5285 Port Royal Road

Springfield, VA 22161

phone: 800.553.6847

fax: 703.605.6900

email: orders@ntis.fedworld.gov

online ordering: http://www.ntis.gov/ordering.htm 


\section{Table of Contents}

Acknowledgements ............................................................................................................... $\mathrm{v}$

Executive Summary ........................................................................................................................ 1

1. Climate Technology Partnership Background...................................................................... 3

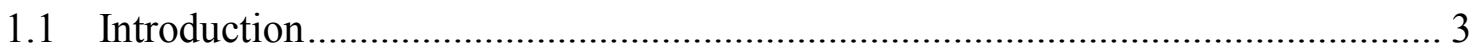

1.2 Role of Technology Cooperation Agreement Pilot Project ....................................... 3

1.3 Strategic Vision of Climate Technology Partnership ................................................ 3

2. Overview of Landfill Gas Projects ............................................................................ 5

2.1 Landfill Gas Emissions and Utilization .............................................................. 5

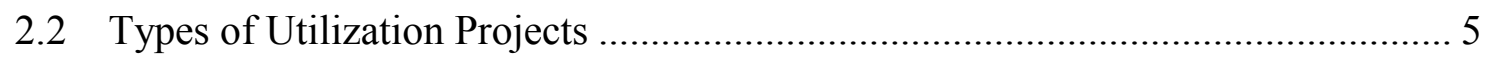

2.3 Why pursue LFG projects in South Korea? .......................................................... 6

2.4 Solid Waste Management in South Korea …………………………...................... 7

2.5 Assessment of Methane Capture Capacity …………............................................... 7

3. Case Studies of LFG Projects in South Korea ................................................................ 8

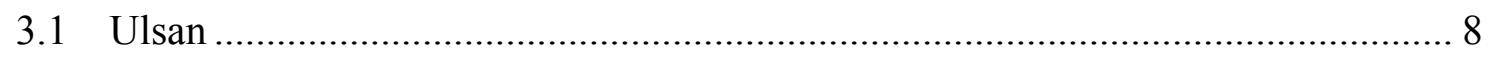

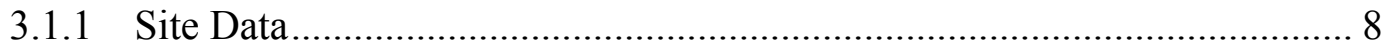

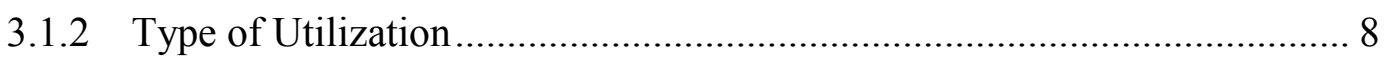

3.1.3 LFG Project Construction ................................................................... 9

3.1.4 Financing Process ......................................................................... 10

3.1.5 Performance Review ....................................................................... 10

3.1.6 Collaboration Process ............................................................................ 11

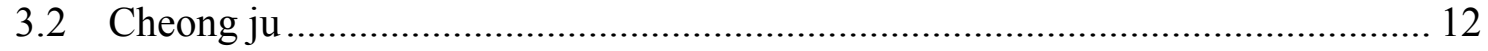

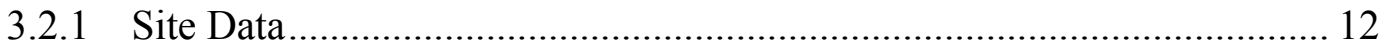

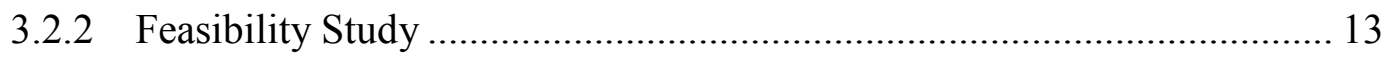

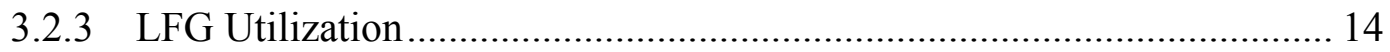

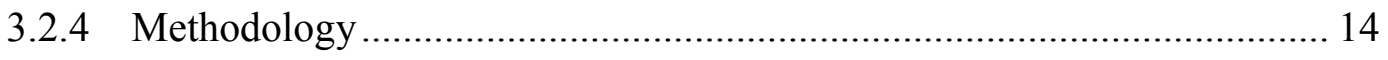

3.2.5 Benefits of Cheong ju LFG Utilization Project ......................................... 15

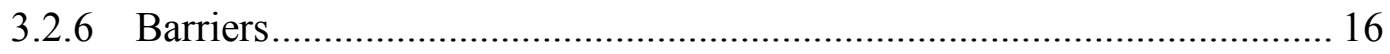


4. Current Status of LFG in Korea .................................................................................... 17

4.1 Number of LFG Projects in Place................................................................. 17

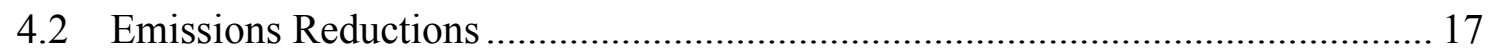

4.3 Collaboration with EPA's Landfill Methane Outreach Program and Methane to Market Partnership ........................................................................................ 18

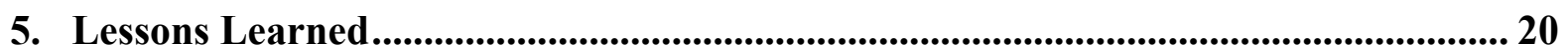

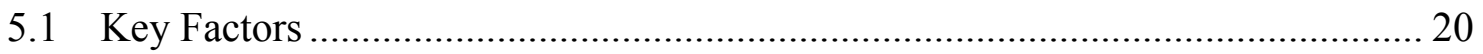

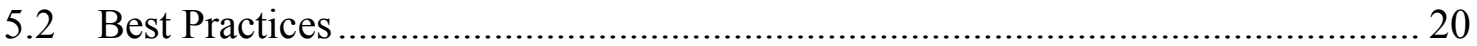

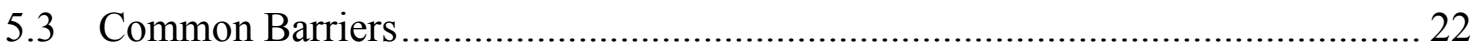

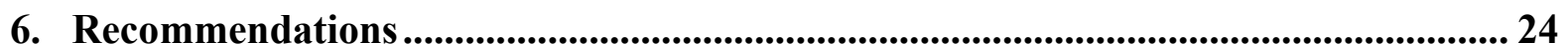

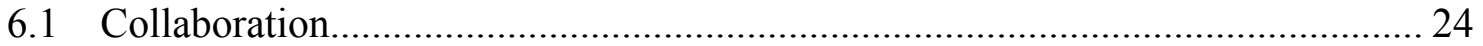

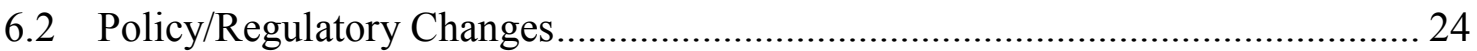

6.3 Capacity Building …………………………............................................... 24

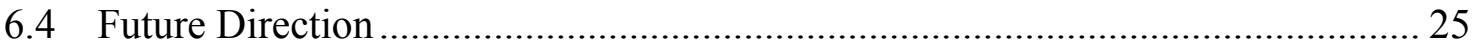

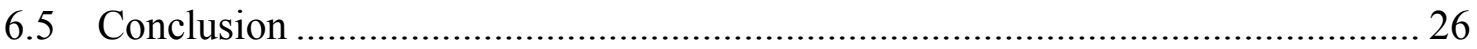

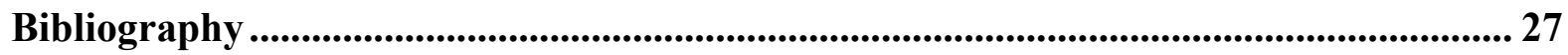

\section{Figures:}

Figure 1: Chart depicting strategic structure of CTP..................................................... 4

Figure 2: Graph of yearly projected LFG output for Ulsan Landfill Site ........................... 8

Figure 3: Pipelines for transporting captured LFG from landfill to adjoining LFG treatment facility .......................................................................................... 9

Figure 4: Photograph of vent at Ulsan Landfill \& Cross sectional views of methane recovery system design for Ulsan ............................................................... 10

Figure 6: Map of South Korea displaying location of Seoul and Cheong ju province .... 13

Figure 7: Location of Cheong ju landfill and lay-out of surrounding area ....................... 15

Figure 8: Best Practices of Ulsan and Cheong ju LFG projects....................................... 21 


\section{Acknowledgements}

This paper was produced by the Technology Applications Center, U.S. Department of Energy's National Renewable Energy Laboratory (NREL) in partnership with the U.S. Environmental Protection Agency (EPA). Principal authors were Christina Larney, Technology Applications Center, NREL and Dr. Mark Heil, International Capacity Building Branch, Climate Change Division, Office of Air and Radiation, U.S. EPA. Gyung-Ae Ha, Project Coordinator, Center for Climate Change Mitigation Projects, Korea Energy Management Company was a contributing author.

Valuable feedback in the form of discussions and written comments were received from Susan Wickwire, Chief, International Capacity Building Branch, Climate Change Division, Office of Air and Radiation, U.S. EPA and Dave Howard, Senior Project Leader, Technology Applications Center, NREL. Both Ms. Ha and Mr. Howard worked closely with the management of the Climate Technology Partnership in Korea and were personally involved with the Ulsan and Cheong ju landfill gas activities. Additional insight regarding methane recovery programs and country specific data was provided by Rachel Goldstein, Program Manager, U.S. EPA Landfill Methane Outreach Program, Brian Guzzone, Team Leader, U.S. EPA Landfill Methane Outreach Program, and Christa Clapp, Economist, Climate Change Division, U.S. EPA. Helpful assistance was also provided by Phil Voss, Senior Project Leader, Technology Applications Center, NREL and Dan Bilello, Group Manager, Technology Applications Center, NREL. Many thanks to each of these individuals for their time and efforts. 


\section{Executive Summary}

This paper touches on several aspects of landfill gas (LFG) projects in South Korea. Two case studies have been drawn from the Climate Technology Partnership (CTP) to provide concrete examples of lessons learned and offer practical guidance for future LFG projects both in Korea and around the world. The main objective of the paper is to describe the circumstances surrounding the Ulsan and Cheong ju LFG projects and then elaborate on the findings. Key factors, best practices, and common barriers are then derived directly from these experiences. Future LFG projects or other activities that involve technology transfer, greenhouse gas mitigation, and sustainable policy implementation can draw on relevant lessons learned in an attempt to maximize benefits and minimize barriers.

There are many circumstances to be considered during LFG project assessment and implementation. These conditions include landfill data (site location, size, etc.), LFG assessment methodology used, organizational relationships of parties involved, regulatory frameworks, and national relevance. The broad range of aspects to be considered points toward a need for collaboration and provides an ideal forum for capacity building. The CTP Korea program worked to assist South Korea at two levels - in "project activity" and "strategic activity" - in a way that encouraged collaborative partnerships. "Project activity" involved technical assistance and trainings that supported the building of relationships and 'know how'. "Strategic activity" focused on outreach and policy frameworks with the goal of building awareness and identifying and addressing regulatory barriers to project implementation and operation.

The two CTP Korea LFG case studies reviewed in this paper are Ulsan and Cheong ju. Ulsan is a fully successful pilot project under CTP and has been operating for nearly four years. The methane gas recovery system at Ulsan is designed to capture the gas from the landfill and transport it to local industrial sites where it is burned in boilers without being purified. The Ulsan landfill gas facility reduces GHG emissions, offsets natural gas as a fuel source, and builds Korea's capabilities to install similar projects. The Cheong ju project has not been realized but the completed feasibility study documents the extensive benefits of LFG projects in general and provides a replicable model for LFG project implementation in South Korea. In response to the Korean government's interest in the program, the feasibility study also offers an analysis template for the requirements of certified emissions reductions (CERs) through the clean development mechanism (CDM).

In addition to environmental concerns, the development of LFG projects in South Korea is propelled by economic and social drivers. Methane recovery can help Korea meet its growing energy needs in a sustainable manner. LFG projects in South Korea have the dual effects of both addressing environmental issues and providing a domestic fuel source. This additional source of domestic fuel is especially important in Korea where over $98 \%$ of the country's energy comes from imported fuels.

South Korea's official policy has the overall mission of "institutionally foster(ing) efficient energy use" ${ }^{1}$ and has been promoting energy efficiency and alternative fuels since

\footnotetext{
${ }^{1}$ Energy Technology Policy in Korea, p. 2.
} 
the 1979 Rational Energy Utilization Act. As environmental harms become more apparent and climate change begins to take on higher relevance, it is becoming increasingly apparent in the energy sector that good business goes hand-in-hand with environmental stewardship. LFG projects not only bring economic benefits but also improve environmental and health conditions. Through hard work and collaboration viable LFG projects can be created that have a substantial net benefit to the environment while meeting or exceeding economic feasibility thresholds.

The lessons learned from Ulsan and Cheong ju have been divided into three categories - key factors, best practices and common barriers. Perhaps the single most important key factor for both of these projects was the involvement of the Korea Energy Management Corporation (KEMCO) as the in-country 'champion' of LFG projects. KEMCO aggressively pursued awareness campaigns as well as provided several other forums for assistance in developing LFG projects. KEMCO's activities included providing basic assessments of potential landfill sites, overseeing and managing the government's revolving fund for financing projects, and coordinating in-country conferences and workshops with the goal of training locals and providing a venue for networking both nationally and internationally.

The best practices that came out of the case studies centered on:

- Capacity building activities for creating the foundation of market transformation which includes installing pilot projects, funding feasibility studies, and planning conferences and workshops

- The role of government in developing markets through programs and partnerships, scoping activities, innovative financing options, policy formulation and regulatory framework revision

- The formation of strategic partnerships between key players which aids capacity building, provides a venue for sharing of expertise, develops networks and know how across organizations, and offers additional avenues for financing

Applications for each of these guidelines can be found in Figure 8, Section 5.2 of this paper.

In conclusion, the paper stresses the need for collaboration in regards to energy issues as well as the need for capacity building to enable market transformation. Capacity building includes several elements, such as improving coordination between distinct governing entities that influence landfill development, augmenting technical know-how of landfill feasibility assessment and development, and creating appropriate regulatory and market conditions to foster self-sustained growth. Recommendations are suggested in the final section of the paper for continued LFG activity. With widespread energy shortages and the growing salience of climate change, LFG projects should continue to be pursued aggressively. Not only because they mitigate GHG emissions and provide better environmental stewardship of landfills, but also due to their viability as business opportunities both in developed and developing nations. 


\section{Climate Technology Partnership Background}

\subsection{Introduction}

To accelerate the implementation of methane recovery technologies in Korea it was determined in 2001 by the Korean and U.S. governments that a new program approach was needed. This is when the Climate Technology Partnership (CTP) was developed with considerable consultation among the U.S. Agency for International Development (U.S. AID), the U.S. Environmental Protection Agency (U.S. EPA), the Department of Energy (DOE), and the National Renewable Energy Laboratory (NREL). CTP is a follow-on from the Technology Cooperation Agreement Pilot Project (TCAPP).

\subsection{Role of Technology Cooperation Agreement Pilot Project}

TCAPP started in 1997 with the goal of developing an international process that assesses needs and fosters private sector development of climate friendly technologies in developing nations. In 1999 Korea joined TCAPP and an assessment of technologies with market-based status, applicable developing country-driven strategy, and available resources was done. This included a sector based technology needs assessment, identification of activities designed to remove barriers, and facilitation of private investment in priority technologies with a focus on partnerships between various stakeholders, including the international business community.

\subsection{Strategic Vision of Climate Technology Partnership}

To better focus resources under CTP Korea, two of the three priority technologies that were identified by TCAPP - energy management and methane recovery - were selected for further development. CTP differed from TCAPP in that it had the added feature of strategic activity to complement project activity. This bifurcation of tasks between strategic and project objectives sought to create a suitable environment for the formation of active new markets in energy service companies and landfill gas (LFG) development. In the area of landfills, the "strategic objectives" addressed structural conditions in Korea such as environmental regulations and landfill management and operations. The "project objectives" pursued development of LFG projects in order to demonstrate the capabilities of the CTP mechanism by the practical application of LFG technologies. Both sets of objectives are complementary.

Creation of a self-sustaining market - whereby private developers seek opportunities to develop landfills, sell landfill gas as fuel, and realize profits - would foster economic growth, create energy security benefits, and reduce GHG emissions. This "market transformation" approach has been successfully applied in other international environmental programs (such as the U.S.-China CFC-Free Super-efficient Refrigerator Project ${ }^{2}$ ), and forms the core of the CTP Korea project.

\footnotetext{
${ }^{2}$ For more information, see EPA case study on the U.S.-China CFC-Free Super-efficient Refrigerator Project, available online - http://www.usctcgateway.net/casestudies/CasestudiesDetail.cfm?LinkAdvID=64730.
} 


\section{Strategic Vision of Climate Technology Partnership}

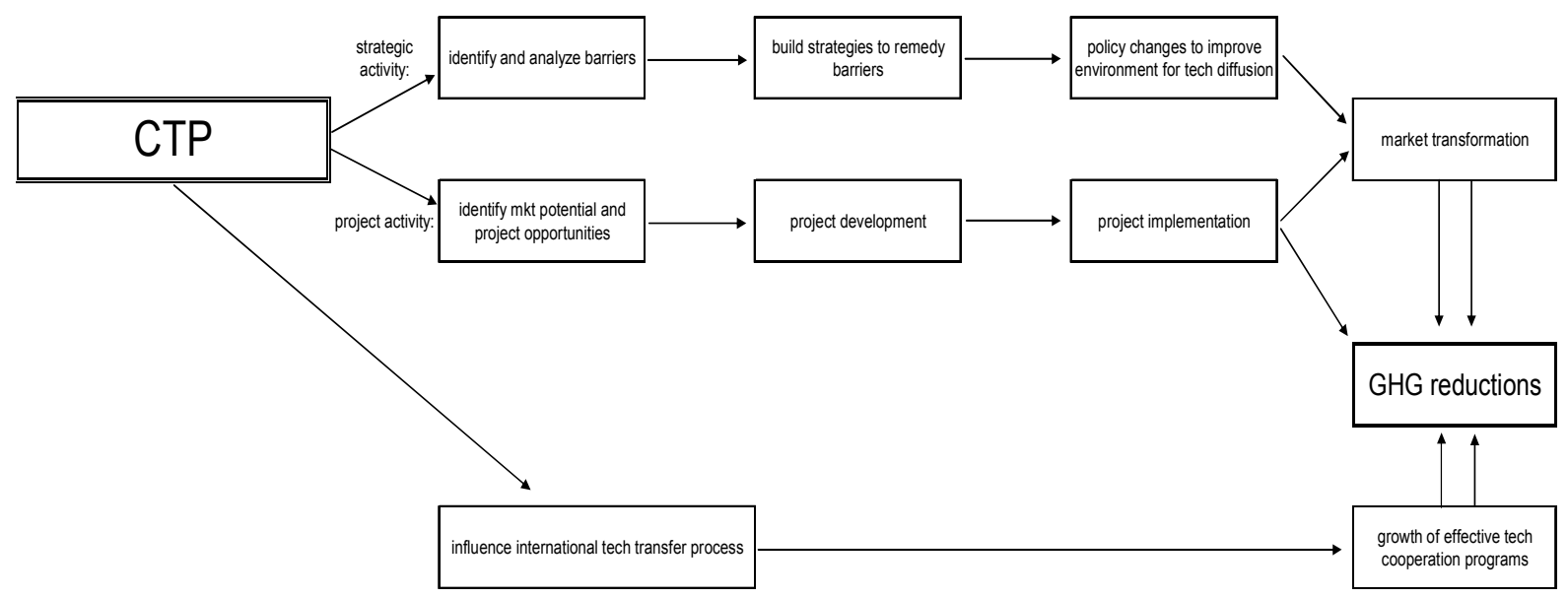

This figure represents the key features and flow of activities of CTP. It depicts the strategic and project activities, and the multiplier effects of market transformation, represented by the double arrows leading to GHG reductions. ${ }^{3}$

\section{Figure 1: $\quad$ Chart depicting strategic structure of CTP}

The market transformation approach aims to harness the dynamism of the private sector to "greatly expand the reach of new technologies so that new projects will continually develop and GHG reductions and other related benefits will be realized on a large scale."4 Application of this approach to the Korean Energy Service Company (ESCO) and landfill sectors demonstrates its potential, and provides a model that can influence the international community's design of technology cooperation programs.

\footnotetext{
${ }^{3}$ CTP Strategic Vision outline, (January 2003, unpublished).

${ }^{4} \mathrm{http}: / /$ www.nrel.gov/environment/korea.html
} 


\section{Overview of Landfill Gas Projects}

\subsection{Landfill Gas Emissions and Utilization ${ }^{5}$}

The waste sector in South Korea accounted for $37.6 \%$ of the countries methane emissions in 2001 with 465 thousand tons of $\mathrm{CH}_{4}$ attributed to this sector. ${ }^{6}$ Municipal solid waste landfills are a large source of these human-related emissions and represent an opportunity to capture and use a significant energy resource. Landfill gas is created as solid waste decomposes at a landfill. This gas consists of about 50 percent methane $\left(\mathrm{CH}_{4}\right)$, the primary component of natural gas, about 50 percent carbon dioxide $\left(\mathrm{CO}_{2}\right)$, and a small amount of non-methane organic compounds.

Instead of allowing LFG to escape into the air, it can be captured, converted, and used as an energy source. Using LFG helps reduce odors and other hazards associated with LFG emissions, and it helps prevent methane from migrating into the atmosphere and contributing to local smog and global climate change. Landfill gas is extracted from landfills using a series of wells and a blower/flare (or vacuum) system. This system directs the collected gas to a central point where it can be processed and treated depending upon the ultimate use for the gas. From this point, the gas can be flared or used to generate electricity, replace fossil fuels in industrial and manufacturing operations, or be upgraded to pipeline quality gas.

\subsection{Types of Utilization Projects ${ }^{7}$}

There are several ways to effectively utilize landfill gas for energy. The two primary applications are electricity generation and direct use. The generation of electricity from LFG can be used on-site or sold to the grid. LFG projects can generate electricity through a variety of different technologies, including internal combustion engines, turbines, micro turbines, Stirling engines (external combustion engine), Organic Rankine Cycle engines, and fuel cells. The vast majority of projects use internal combustion (reciprocating) engines or turbines, with micro turbine technology being used at smaller landfills and in niche applications. Certain technologies such as the Stirling and Organic Rankine Cycle engines and fuel cells are still in the development phase.

Employing LFG directly to offset the use of other fuel sources (natural gas, coal, oil) is another means by which current projects make use of captured LFG. This direct use of LFG can be in a boiler, dryer, kiln, greenhouse, or other thermal applications. It can also be used to evaporate leachate. Innovative direct uses include firing pottery and glass blowing kilns; powering and heating greenhouses and ice skating rinks; and heating water for aquaculture . Current industries using LFG include auto manufacturing, chemical production, food processing, pharmaceutical, cement and brick manufacturing, wastewater treatment,

\footnotetext{
${ }^{5}$ Section 2.1 contributed by Rachel Goldstein, Landfill Methane Outreach Program (LMOP), U.S. EPA. LMOP is described in section 4.3.

${ }^{6}$ Ministry of Environment, Republic of Korea, "Korea's Efforts to Reduce Climate Change and Methane Emissions, presentation at Methane to Markets Conference, (Buenos Aires, Brazil - November 2005).

Available online -

http://www.methanetomarkets.org/events/2005/all/docs/presentations/steering/korea.pdf

${ }^{7}$ Section 2.2 contributed by Rachel Goldstein, Landfill Methane Outreach (LMOP), U.S. EPA.
} 
consumer electronics and products, paper and steel production, and prisons and hospitals, among others.

An additional use of LFG is in cogeneration (also known as combined heat and power or CHP) projects that generate both electricity and thermal energy, usually in the form of steam or hot water. Several cogeneration projects have been installed at industrial operations, using both engines and turbines. The efficiency gains of capturing the thermal energy in addition to electricity generation can make these projects very attractive during LFG project consideration.

Production of alternate fuels from LFG is an emerging area. Landfill gas has been successfully delivered to the natural gas pipeline system as both a high-Btu and medium-Btu fuel. LFG has also been converted to vehicle fuel in the form of compressed natural gas $(\mathrm{CNG})$, with a number of liquefied natural gas (LNG) and methanol production projects in the planning stages.

\subsection{Why pursue LFG projects in South Korea?}

Korea has a rapidly growing economy and depends extensively on imported fuels that account for $98 \%$ of its energy use. ${ }^{8}$ There are few reliable energy sources within Korea. Thus, Korea has a compelling need to develop alternate fuel sources to enhance its energy security, economy, and environment. Methane recovery is a suitable source of fuel for Korea considering its high population density, rapid economic development, and urbanization. These factors contribute to large concentrations of refuse as well as steady flows of solid wastes into landfill sites which are critical for viable methane recovery projects.

There is also the concern regarding climate change due to methane's powerful role as a GHG with a global warming potential (GWP) of 23. ${ }^{9}$ Carbon dioxide's GWP is 1; there is thus a significant net reduction in radiative forcing by capturing methane. ${ }^{10}$ Over the last two centuries, methane concentrations in the atmosphere have more than doubled, largely due to human-related activities. Methane now accounts for $16 \%$ of global GHG emissions from human activities. ${ }^{11}$ Due to its significant role as an anthropogenic GHG, methane is an optimal target for emissions reduction.

While some LFG projects were already being contemplated and pursued in Korea, CTP has catalyzed its further development by listing landfills suitable for development,

\footnotetext{
${ }^{8}$ Korea Energy Economics Institute. 2004. Energy Info Korea. Seoul.

${ }^{9}$ Global warming potentials are used to compare the abilities of different GHGs to trap heat in the atmosphere. GWPs are based on the radiative efficiency (heat-absorbing ability) of each gas relative to that of carbon dioxide, as well as the decay rate of each gas (the amount removed from the atmosphere over a given number of years) relative to that of carbon dioxide. GWP provides a construct for converting emissions of various gases into a common measure. The generally accepted authority on GWPs is the Intergovernmental Panel on Climate Change. Its Third Assessment Report (2001) estimates the GWP of methane at 23. Source: Energy Information Administration, DOE. http://www.eia.doe.gov/oiaf/1605/gwp.html

${ }^{10}$ Feasibility Study, SCS Engineers, DRAFT - "Feasibility Assessment Report for a Landfill Gas Utilization/Greenhouse Gas Mitigation Project at the Megalo Landfill, Cheong ju, South Korea," (April 2004), p 26.

${ }^{11}$ EPA website, http://www.epa.gov/methanetomarkets/.
} 
providing high-quality feasibility studies, helping reduce regulatory barriers, and informing Korean and international developers of market opportunities.

\subsection{Solid Waste Management in South Korea ${ }^{11}$}

Historically, municipal solid waste generated in South Korea has been disposed of at open landfill sites. However, during the past ten years there has been recognition of the issues associated with environmental protection and as a result, poorly located and operated disposal facilities are being closed and replaced by modern regional disposal facilities. Municipal solid waste is increasingly viewed as a potential resource and there is a strong trend toward implementation of recycling, composting, and combustion technologies.

Utilizing landfill gases from expired landfill sites is an emerging business in the solid waste treatment market. For example, the city of Seoul installed 100 methane gas extraction wells at the former Nanji landfill site. The captured gas from these wells is sent to the Korea District Heating Corporation (KDHC). KDHC combusts the gas and distributes the heat energy to neighboring facilities and households for heating and cooling. The Seoul World Cup Stadium is one of the facilities supplied with heat from the LFG project at Nanji.

\subsection{Assessment of Methane Capture Capacity ${ }^{12}$}

One of the most important factors in considering landfill gas projects in South Korea is the ability to accurately assess the methane recovery potential for each site. U.S. EPA developed an air emissions model for assessing landfills in the U.S. called LandGEM. Korean waste composition differs significantly from that in the U.S., so EPA's Landfill Methane Outreach Program (LMOP) adjusted LandGEM to more accurately reflect the conditions in Korea. The LandGEM model developed for the Korean landfills was modified by comparing Korean with U.S. waste characteristics in terms of organic content, moisture content, and degradation rates of different waste components, and adjusting the model to account for the effects of these differences on landfill gas generation.

The model developed for the Cheong ju feasibility study was derived from the U.S. EPA LandGEM model using a similar method described in detail in the 1996 IPCC Workbook and Reference Manual and the IPCC Good Practice Guidance and Uncertainty Management in National Greenhouse Inventories document. This model is addressed further in Section 3.2.2. At the Ulsan site, measurements of methane and LFG flows from existing actively operating gas wells were used to develop estimates of the amount of recoverable LFG at the landfill. This required evaluating the volume of refuse contributing LFG to the wells in order to develop an estimate of potential LFG recovery from the entire landfill.

\footnotetext{
${ }^{11}$ Section 2.4 contributed by Gyung-Ae Ha, Korea Energy Management Corporation.

${ }^{12}$ Section 2.5 contributed by Brian Guzzone and Rachel Goldstein, Landfill Methane Outreach Program (LMOP), EPA.
} 


\section{Case Studies of LFG Projects in South Korea}

\subsection{Ulsan}

\subsubsection{Site Data}

The Ulsan site is a municipal landfill with a capacity of $4,255,142 \mathrm{~m}^{3}$. The site was opened in 1994 and is expected to close in 2014. In 1999 Ulsan had 2,297,000 $\mathrm{m}^{3}$ of wastein-place that was producing approximately $27 \mathrm{~m}^{3}$ of LFG/minute. ${ }^{13}$ The City of Ulsan decided to move forward with the landfill gas project after a feasibility study had been conducted. The construction of the LFG capture and transportation structures was started in November 2001, and by August 2002 commercial LFG production had begun.

The Ulsan feasibility study was completed by using actual measurements - not projected solely from a model. The diagram below shows projected methane production per year over the lifetime of the project and beyond. It indicates that methane production will be at its highest from 1998 to 2018 with a dramatic drop in output closely following the expected closure of the landfill in 2014.

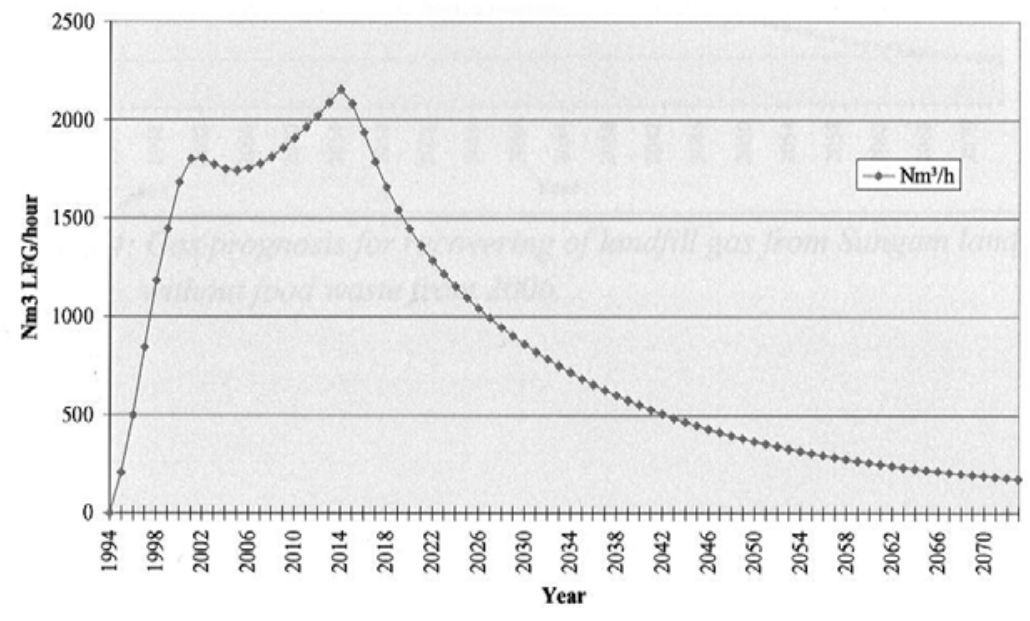

Figure 2: $\quad$ Graph of yearly projected LFG output for Ulsan Landfill Site

\subsubsection{Type of Utilization}

The methane gas recovery system at Ulsan is designed to capture the gas from the landfill and transport it to an adjoining chemical factory - Kumho Chemical Ltd. - where it is burned in boilers without being purified. Figure 3 (below) shows the pipelines that now transport the LFG generated at the landfill to the boilers at Kumho Chemical Ltd.

\footnotetext{
${ }^{13}$ Ha, Gyung-Ae, Korea Energy Management Corporation, “Landfill Gas Project in South Korea,” presentation at $5^{\text {th }}$ Annual LMOP Conference, (Washington DC - December 2001).
} 


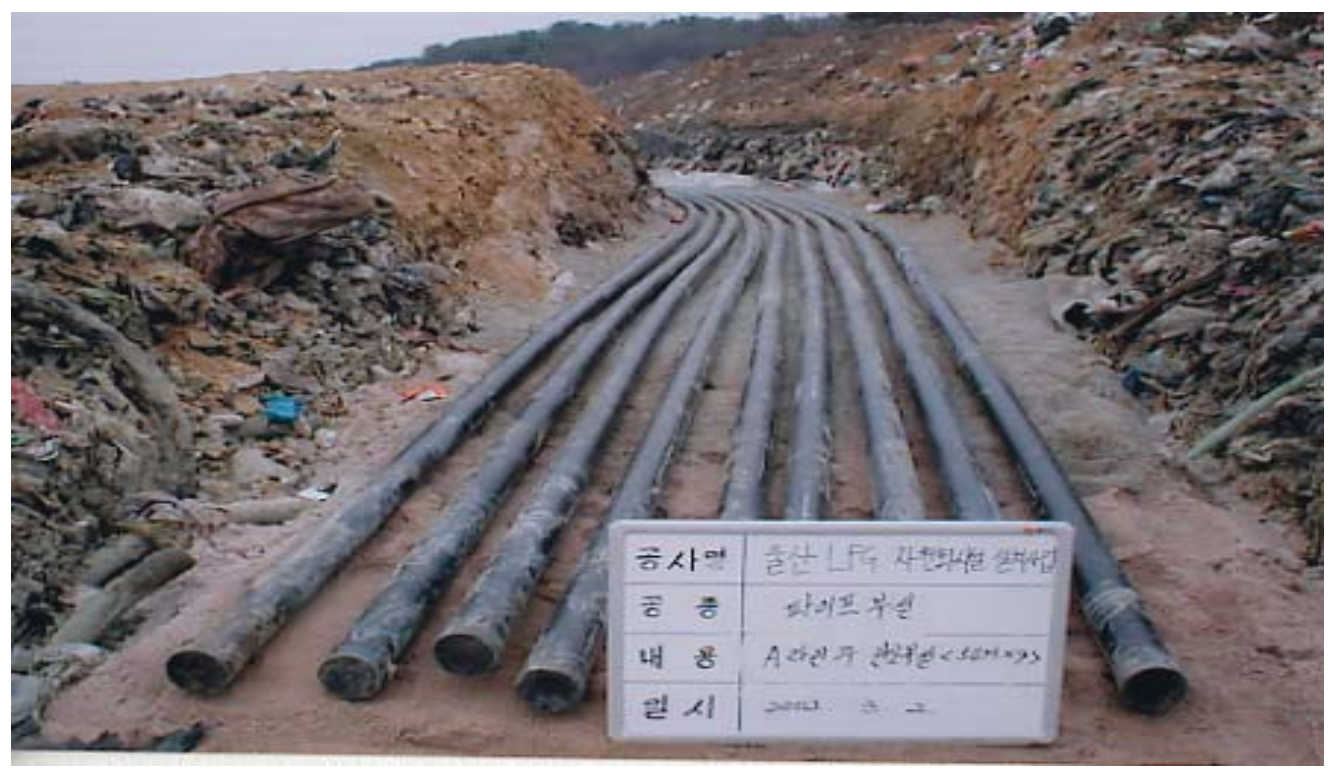

Figure 3: $\quad$ Pipelines for transporting captured LFG from landfill to adjoining LFG treatment facility

\subsubsection{LFG Project Construction}

The construction duration of the Ulsan project was from 2000-2002. The project proceeded with relatively few obstacles and has been operating since 2002. The few barriers that were encountered were largely due to a lack of experience regarding LFG utilization projects. SK Corporation (SK) overcame its inexperience in designing LFG projects by attending trainings in Korea sponsored by the U.S. EPA and by visiting the U.S. to tour landfill sites with LFG projects in place.

SK initiated a feasibility study in November 2000 . Once the study was completed and the City of Ulsan decided to proceed with the project, various Korean companies bid on the construction of the methane gas recovery system. SK Corporation was awarded the project in September 2001 and construction began in December of the same year. 


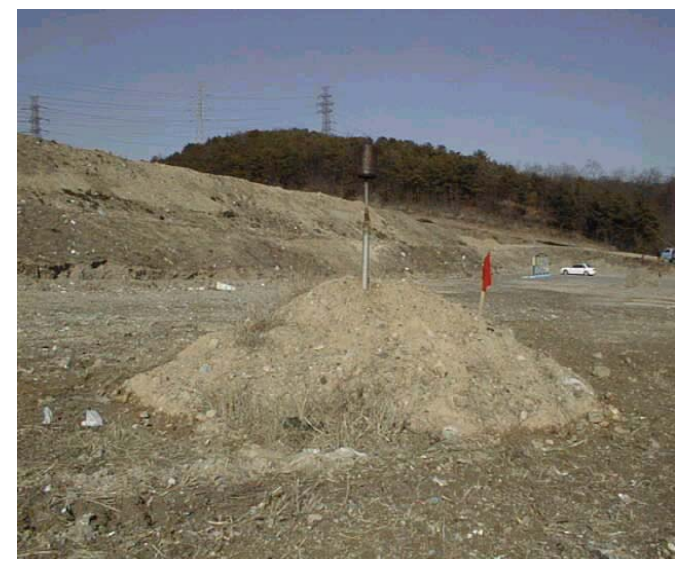

The above vent can be converted into an extraction well and used in a methane recovery system similar to the one shown on the right.
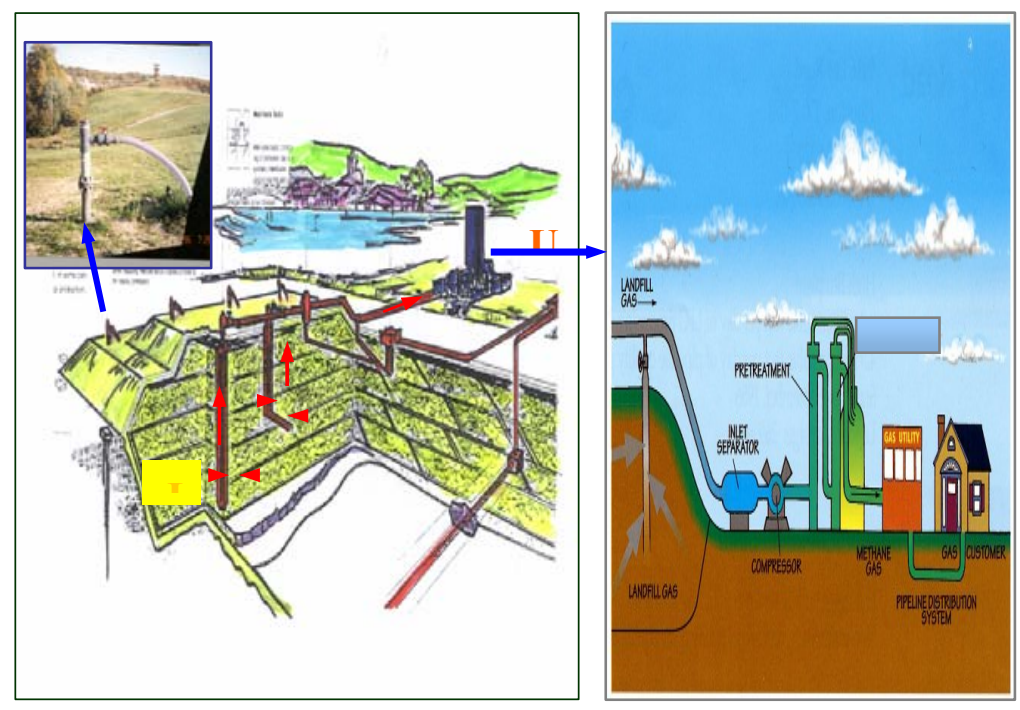

Figure 4: $\quad$ Photograph of vent at Ulsan Landfill \& Cross sectional views of methane recovery system design for Ulsan

\subsubsection{Financing Process}

The construction costs of the methane recovery system were funded by SK Corporation. SK received funding through a commercial bank loan that was part of a revolving fund established by the Korean Energy Management Corporation (KEMCO). U.S.\$4,000,000 was covered by SK for construction ${ }^{14} \mathrm{SK}$ will pay back the fund for 10 years from sales of LFG and donate the facility to the city after that 10 years.

The revolving fund established by KEMCO could be financed through several different banks in South Korea. This gives the borrower greater flexibility in choosing an institution. Both SK Corporation and the City of Ulsan applied for and received a recommendation letter from KEMCO that supported the project. SK and Ulsan each took their letters and applied for a loan at the bank of their choice, most likely the institution where they conducted business previously.

\subsubsection{Performance Review}

The performance of the plant has met expectations. The market value of the methane gas supplied to the boiler over the lifetime of the project was estimated at U.S. $\$ 3,400,000$ during the construction phase. ${ }^{15}$ In 2005 , a total of $15,980 \mathrm{~m}^{3} /$ day of LFG was produced. This LFG is being used as a fuel replacement for natural gas. The market value of natural gas in Korea is approximately U.S. $\$ .50 / \mathrm{m}^{3}$ at present. This equates to a weekly value of U.S.\$55,930 for the $15,980 \mathrm{~m}^{3}$ of LFG delivered each day from Ulsan. ${ }^{16}$

\footnotetext{
${ }^{14}$ Ulsan LFG 2 page summary, www.pi.energy.gov/pdf/library/EWSL/EWSLkorea.pdf.

15 Ibid.

${ }^{16}$ This figure is arrived at by using a 1:1 correlation between LFG gas and natural gas used.
} 
The benefit of LFG fuel is increasingly valuable as traditional fuel prices rise. In 2002 , the replacement value of the $43,200 \mathrm{~m}^{3}$ of LFG supplied to Ulsan was U.S. $\$ 15,900$. In subsequent years natural gas prices continued to rise by varying amounts which placed the replacement value of the $43,200 \mathrm{~m}^{3}$ of LFG supplied by Ulsan at U.S. $\$ 17,442$ in 2003 , U.S.\$18,414 in 2004, and U.S.\$19,177 in 2005. These figures demonstrate the savings a facility can experience by using LFG which has a stable cost over the lifetime of the project. If this cost were equal to the cost of natural gas in 2002 and remained stable, the facility would be saving U.S.\$5,783/day in comparison to a facility that was running on natural gas.

The savings in GHG emissions was estimated to total 101,475 metric tons of $\mathrm{CO}_{2}$ equivalent per year. ${ }^{17}$ If these reductions were sold as carbon offsets in the world market they would be worth U.S. $\$ 507,375$ each year using the value of $\$ 5 /$ metric ton of $\mathrm{CO}_{2}$ equivalent. This equates to between U.S.\$6,088,500-9,132,750 for the 12 to 18 year life span of the project. In combination, the value of the fuel and carbon offsets makes the choice to build the facility a sound economic decision. The motivation to build this project becomes even stronger when the added benefits of energy security, health standards, and environmental stewardship are considered.

\subsubsection{Collaboration Process ${ }^{18}$}

It is important to note that this project was not accomplished by a single entity or even a partnership of a few entities. The Ulsan facility was a partnership on varying levels of several organizations which included: Ulsan city officials, U.S. Environmental Protection Agency, Republic of Korea's Ministry of Environment, SK Corporation, LFG Consult Aps of Denmark, United States-Asia Environmental Partnership, U.S. Department of Energy, National Renewable Energy Laboratory, the Korean Ministry of Commerce, Industry, and Energy (MOCIE) and the Korea Energy Management Corporation. The willingness of all involved to work together and the initiative taken by key groups combined to achieve the realization of the Ulsan LFG facility.

The central player for the Ulsan project was SK Corporation. Once KEMCO identified the site and Ulsan city officials expressed an interest in its development, SK became the dominant force behind the project. Once involved, SK aggressively pursued the project and encouraged Ulsan city officials to do the same. While KEMCO was the champion in identifying LFG projects and getting parties interested, SK Corporation took over as the champion in the Ulsan project and ensured project implementation and completion.

Another important collaboration that took place during the Ulsan project was that between SK and LFG Consults Aps, a Danish consulting company. SK Corporation first met a representative of the LFG Consults Aps at a conference regarding landfill management in South Korea. The Dutch company gave a presentation at the conference which sparked the interest of SK Corporation. SK initiated contact with LFG Consults Aps at the conference and the companies began to explore the formation of a partnership.

\footnotetext{
${ }^{17}$ Ulsan LFG 2 page summary, www.pi.energy.gov/pdf/library/EWSL/EWSLkorea.pdf.

${ }^{18}$ Large portion Section 3.1.6 was contributed by Gyung-Ae Ha, Korea Energy Management Corporation in describing the evolving relationships between SK Corporation and their international partners.
} 
SK asked LFG Consults Aps to conduct a feasibility study of the LFG project at Ulsan. During the same time frame, KEMCO had contacted a U.S. engineering firm about taking part in the project. The firm originally expressed interest in November 1999 during a program stage of TCAPP in which KEMCO and NREL were looking for companies interested in working on LFG projects in Korea. The engineering firm expressed interest in market opportunities in Korea during the TCAPP phase, and visited the country in January 2000, accompanied by a KEMCO representative.

SK Corporation began communicating with both LFG Consult Aps and the U.S. engineering firm about partnering. When SK received the contract for the LFG recovery work from Ulsan City, the SK team tentatively decided to go forward with the design of the LFG facility and have the U.S. firm provide design review and supervision during construction. The U.S. firm and SK failed to arrive at an agreement during the cost negotiation process, however. In the end, SK decided to work with LFG Consult Aps regarding the implementation of the project.

A convergence of participants and activities provided a critical mass that enabled the project to succeed. The role of each participant in the pursuit and completion of the Ulsan project varied greatly in scope but all were significant.

"Ulsan City officials were open to installing a landfill methane project in their city, attended a workshop conducted by the U.S. EPA's Landfill Methane Outreach Program (LMOP) in Korea, completed the project, and funded the installation. The Republic of Korea's Ministry of Environment implemented standards that changed they way waste is disposed of in landfills, resulting in landfills that have the improved potential to be developed for methane recovery. SK Corporation conducted an independent assessment of the site, installed the project, and will use the gas. LFG Consult Aps conducted a feasibility study for SK Corporation to determine the capability of the landfill to generate gas and helped with project design. The United States-Asia Partnership provided initial funding for the U.S. DOE's National Renewable Energy Laboratory and the U.S. EPA to pursue development of a Clean Technology Initiative in Korea." 19

\subsection{Cheong ju}

\subsubsection{Site Data}

Cheong ju is an inland city located 128 kilometers southeast of Seoul. The city occupies an area of 153 square kilometers and has a population of approximately 595,000 people. It is estimated that 700 metric tons of municipal solid waste is currently generated per day in Cheong ju. This equates to roughly 250,000 metric tons per year. Of this total, 50,000 are currently managed by recycling, composting, and incineration. The remaining 200,000 metric tons per year are disposed at the site.

\footnotetext{
${ }^{19}$ Ulsan LFG 2 page summary, www.pi.energy.gov/pdf/library/EWSL/EWSLkorea.pdf.
} 


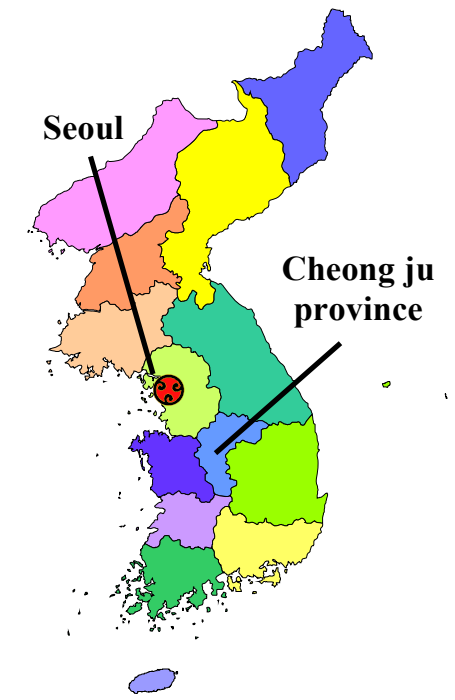

Previously, municipal solid waste that was generated in Cheong ju was disposed at the Moonam Landfill, which served as the main disposal facility for Cheong ju province from 1994 to 2000. A new site, the Megalo landfill, opened in 2001 and has replaced Moonam as the primary disposal facility for Cheong ju province. The feasibility study for Cheong ju focuses on the Megalo site.

Figure 6: Map of South Korea displaying location of Seoul and Cheong ju province

\subsubsection{Feasibility Study}

The Megalo Landfill site in Cheong ju was chosen to receive funding for a feasibility study by KEMCO and U.S. EPA LMOP. The city asked KEMCO to develop the project, which is a new model for developing these LFG projects. The study for Cheong ju was prepared in August 2002 by SCS Engineers in the United States in cooperation with Wetherill Environmental of New Zealand. The purpose of the study was not only to identify and evaluate the technical aspects of a landfill gas project at the Megalo site, but also to analyze the institutional and economic factors associated with developing a LFG utilization and gas mitigation project.

The study "found site conditions ... to be conducive for development of a commercial LFG recovery and utilization project." ${ }^{20}$ An analysis of the site found that the current system of LFG vents could be modified as vertical extraction wells and additional wells could be installed to capture gases from $80 \%$ of the landfill area. With a $75 \%$ efficiency rating these vents would be able to recovery $60 \%$ of the generated landfill gas from the site. If desired, the vents could be expanded at a later date to cover $100 \%$ of the landfill area for a $75 \%$ capture rate of the available landfill gas. This efficiency rating correlates well with the 60$85 \%$ range established by the U.S. EPA. ${ }^{21}$

It was also "recommended that the project development proceed in a phased manner." 22 In using a phased approach, LFG capture can be monitored to determine the actual rate of landfill gas production. Once this actual rate of landfill gas is verified, the project can proceed with confirmed data, which is more reliable than projections or estimates.

\footnotetext{
${ }^{20}$ Feasibility Study, p. 31 .

${ }^{21}$ Ibid, p. 12.

${ }^{22}$ Ibid, p. 33.
} 


\subsubsection{LFG Utilization}

The Cheong ju feasibility study was concerned solely with the capture, monitoring, and flaring of LFG gas. No economic consideration was made for a proposed $0.5 \mathrm{MW}$ power generation facility or other utilization options. From initial projections of LFG generation at the site, it is feasible that a facility producing $0.5 \mathrm{MW}$ of electricity could be operational for 12-15 years at the Megalo landfill. ${ }^{23}$ The cost effectiveness of this option was not analyzed but it is assumed that the equipment could be moved to a different site when methane capture rates no longer warranted electricity production at Megalo.

\subsubsection{Methodology}

It is important to note that any feasibility study is only as good as the model and data that are used. Most of the data for analysis was supplied to SCS Engineers by the local government of Cheong ju with KEMCO as the intermediary. The projected landfill gas generation rates are highly dependent on the provided parameters and the responsibility for the accuracy of the feasibility study is shared by SCS, KEMCO, and Cheong ju.

The basic model used in the feasibility study for calculating methane generation potential has five parameters which include:

$$
\begin{aligned}
& \mathrm{L}_{0}=\quad \text { methane generation potential }\left(\mathrm{m}^{3} / \mathrm{yr}\right) \\
& \mathrm{R}=\quad \text { average annual waste acceptance rate }\left(\mathrm{m}^{3} / \mathrm{Mg}\right. \text { of refuse) } \\
& \mathrm{k}=\text { methane generation rate constant }(1 / \mathrm{yr}) \\
& \mathrm{c}=\quad \text { time since/to landfill closure }(\mathrm{yr}) \\
& \mathrm{t}=\quad \text { time since landfill opened }(\mathrm{yr})
\end{aligned}
$$

These 5 parameters are used to calculate:

$$
\mathbf{Q}=\text { methane generated in current year }\left(\mathrm{m}^{3} / \mathrm{yr}\right)
$$

By finding accurate values for the five factors one can discern the amount of methane generated in the current year $\left(\mathrm{m}^{3} / \mathrm{yr}\right)$ with the following equation:

$$
\mathbf{Q}=\mathbf{L}_{0} \mathbf{R}\left(\mathrm{e}^{-\mathrm{kc}}-\mathrm{e}^{-\mathrm{kt}}\right)
$$

This equation can be modified to take into account variances in the parameters such as differences in annual acceptance rates for a landfill.

The parameters $\mathrm{L}_{0}, \mathrm{R}, \mathrm{k}$, c, and $\mathrm{t}$ will vary for each landfill site. Factors $\mathrm{R}, \mathrm{c}$, and $\mathrm{t}$ will be the easiest to measure. The operators of the site should have the appropriate data to provide accurate information on landfill opening and closing dates as well as the average annual acceptance rate for the site. Parameter $\mathrm{k}$, methane generation rate constant (1/yr), is a bit more complicated, as it takes into account various factors which include moisture content

\footnotetext{
${ }^{23}$ Ibid, p. 18.
} 
of refuse, availability of nutrients for methanogens, $\mathrm{pH}$, and temperature. Once a LFG recovery system is in place, this rate can be monitored to more accurately determine a value for $\mathrm{k}$.

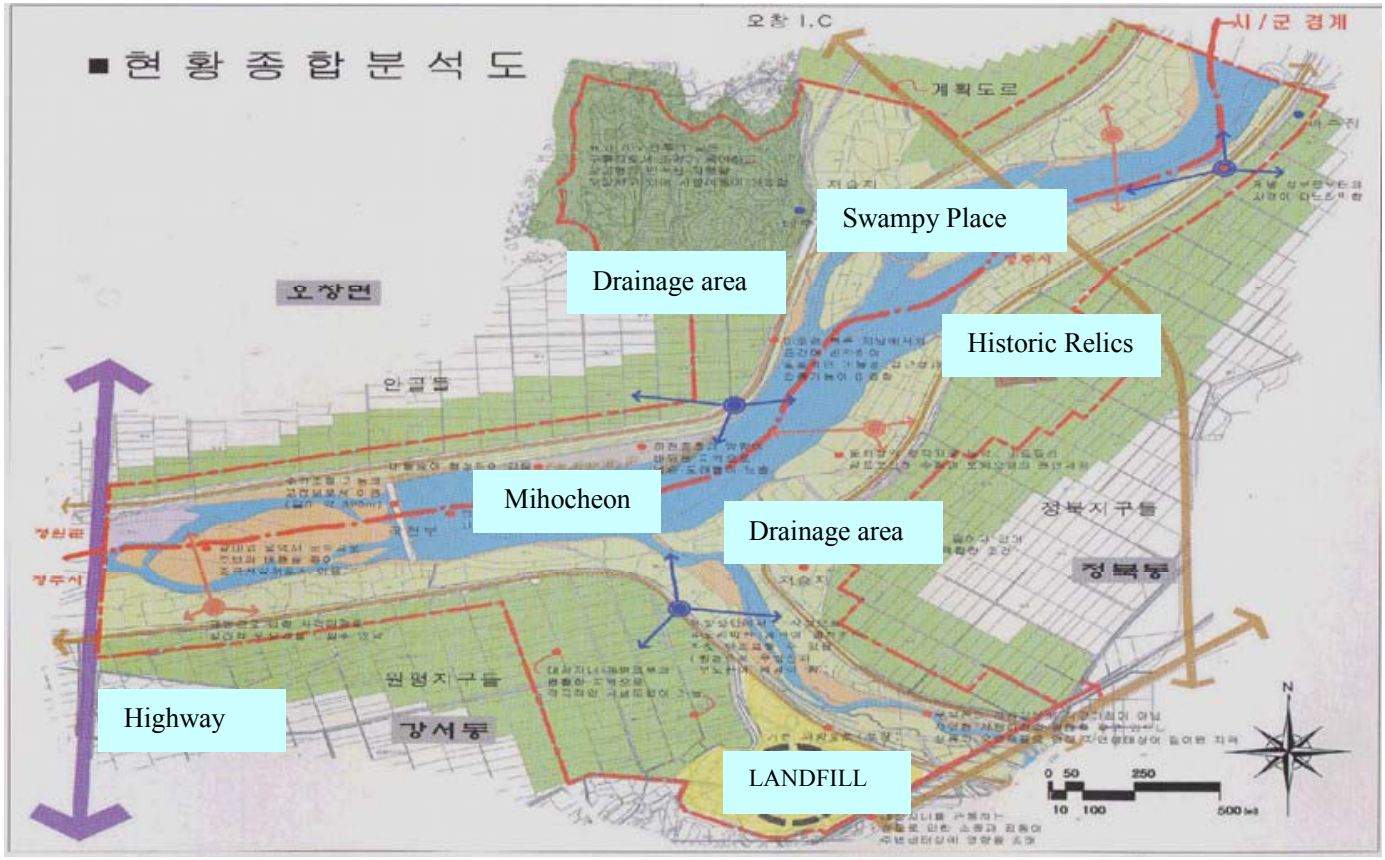

Figure 7: $\quad$ Location of Cheong ju landfill and lay-out of surrounding area

In considering this methodology for South Korea, the parameter which represents methane generation potential, $\mathrm{L}_{0}$, needed to be recalculated. The default value used in the U.S. for this datum was not applicable to solid waste in South Korea due to the very different compositions of refuse between the two countries. "Therefore a calculation of the value for $\mathrm{L}_{0}$ was made based on the composition of the local waste stream using IPCC methodology and this estimate was adjusted to allow for the high moisture content of the waste." 24

\subsubsection{Benefits of Cheong ju LFG Utilization Project}

The overall benefits of the Megalo LFG utilization and gas mitigation project were substantial. They are listed below and often apply to LFG projects in general:

- Social and environmental benefits to the community from the utilization of alternative energy and reduced fossil fuel consumption

- Use of facility as a tour site to promote awareness and knowledge of greenhouse gas mitigation and renewable energy projects

- Consistent with international, national, and local objectives for sustainable development

\footnotetext{
${ }^{24}$ Feasibility Study, p. 11.
} 
- Improved management of municipal solid waste (reduces pollution \& overall landfill costs)

- Reduction of methane emissions

- Potential of displacing fossil fuel use and improving air quality

- Domestic source of energy/fuel

- Develops local capacity for taking on and completing additional LFG projects

- Can be used to develop 'turn key' approach to similar projects

- Provides good focal point for dissemination of information

These benefits, combined with the feasibility study's finding that "the proposed GHG mitigation project is considered to be economically feasible ... [with] ... a price of U.S. $\$ 4.00$ per metric ton of $\mathrm{CO}_{2}$ equivalent, ${ }^{25}$ make a strong case for the Cheong ju government to install a LFG recovery and GHG mitigation project at Megalo landfill.

\subsubsection{Barriers}

Despite the various documented benefits and positive findings of the feasibility study, an LFG system has not been constructed at the Megalo landfill in Cheong ju. There are a number of factors that contribute to the lack of action on this project. Two of the main barriers that will need to be overcome in pursuing the project are 1) local officials' lack of commitment to the project and 2) difficulty in qualifying for certified emission reductions (CERs) under the clean development mechanism (CDM). An important impetus for pursuing LFG projects is the interest of the Korean government in gaining CERs under CDM.

After reviewing the feasibility study, local officials at Cheong ju decided to not pursue the project further. The specific reasons for this decision have not been made clear to KEMCO or other partners. There seems to have been a shift in commitment by local officials which put an end to developing the project further. It also appears that local officials were more interested in developing the older landfill site, Moonam, and were not enthusiastic about the study's suggestion to develop the Megalo landfill as the better candidate.

The shifting commitments of elected officials can create significant limitations on finding viable projects for development. Also, there can be considerable delays when working with governments due to election cycles and lengthy decision making processes. These factors can affect projects in different ways and highlight the difficulties that can be encountered when working with government.

\footnotetext{
${ }^{25}$ Ibid, p. 33.
} 


\section{Current Status of LFG in Korea}

\subsection{Number of LFG Projects in Place}

There has been a significant increase in the number of LFG projects across Korea. Market transformation as a result of CTP is most noticeable in the methane capture area. At the time that CTP started [i.e. 2002] in Korea a few landfills were considering the idea of LFG projects. Currently there are at least 17 LFG utilization projects either completed or in the latter stages of development. Four of these projects have direct use applications and fourteen use the captured LFG to produce electricity with a total capacity that will be just over $80 \mathrm{MW} .{ }^{26}$ There is also one landfill, Hyeul-Dong near Chuncheon city, which is currently planning to convert 80 trucks to run on $\mathrm{CNG}$ produced from captured methane at the landfill. ${ }^{27}$ Not all of these LFG projects can be linked to CTP Korea, but the CTP mechanism, by forging productive relationships and providing a positive demonstration effect, likely boosted the market and this momentum continues to exert a favorable influence for project development.

\subsection{Emissions Reductions}

The two LFG projects that were reviewed in this paper had an estimated reduction of 1,165,786 metric tons of $\mathrm{CO}_{2}$ equivalent - a reduction of 925,740 metric tons of $\mathrm{CO}_{2}$ for Ulsan and a reduction of 240,046 metric tons of $\mathrm{CO}_{2}$ for Cheong ju according to U.S. EPA figures. ${ }^{28}$ There have also been several other LFG projects in Korea - Busan, Daegoo, Daejeon, Gwangju, Wonju, Goonsan, Pohang, Sung-am, Masan, Jeju, Yeo-su, and Sooncheon. The total emissions reductions for these projects are approximately 900,000 metric tons of $\mathrm{CO}_{2}$ and $\mathrm{CH}_{4}$.

Currently, about 7 LFG projects including Sudokwon landfill, Daegu landfill and Yosu landfill are in the pipeline of CDM project. The Korean government hopes these projects will create important documentation of the empirical results of GHG emission reductions from LFG activity in Korea, as well as help it gain familiarity with the program. Additionally, the government is optimistic that these projects may provide the necessary groundwork toward improving the economic feasibility of smaller GHG mitigation projects. Due to extensive transaction costs that were incurred for CDM projects initially, only large GHG mitigation projects found participation economically viable. An alternative under consideration by Korean developers is to bundle several smaller projects in an attempt to reach economic feasibility, but this too has limitations and requires extended planning and cooperation.

\footnotetext{
${ }^{26}$ Total is 18 because one site generates electricity and supplies gas for direct use.

${ }^{27}$ Chan-su, Kang, "Garbage power gains fans as oil price soars," JoongAng Daily, (November 26, 2005). Available online -

http://joongangdaily.joins.com/200511/25/200511252204486009900090609062.html

${ }^{28}$ U.S. EPA, “CTP Total Emissions Reductions,” (2004, unpublished). (excel spreadsheet w/ landfill \& ESCO estimated reductions)
} 


\subsection{Collaboration with EPA's Landfill Methane Outreach Program and Methane to Market Partnership}

U.S. EPA's Landfill Methane Outreach Program (LMOP) is a voluntary assistance program that helps to reduce methane emissions from landfills by encouraging the recovery and use of landfill gas as an energy resource. LMOP forms partnerships with communities, landfill owners, utilities, power marketers, states, project developers, tribes, and non-profit organizations to overcome barriers to project development by helping them assess project feasibility, find financing, and market the benefits of project development to the community. U.S. EPA launched LMOP to encourage productive use of this resource as part of the United States' commitment to reduce greenhouse gas emissions under the United Nations Framework Convention on Climate Change (UNFCCC). ${ }^{29}$

One of South Korea's first interactions with LMOP was in 2002 during the Cheong ju feasibility study. Consultations between the LMOP and South Korea have continued throughout CTP. In December of 2004 South Korea discussed joining the Methane to Markets (M2M) Partnership with U.S. EPA at the Tenth Conference of Parties to UNFCCC.

By becoming a member of the M2M Partnership South Korea made a strong commitment to continuing the work of CTP Korea LFG projects. Partners take on an extensive list of tasks when they join that seek to:

- Identify and promote areas of bilateral, multilateral, and private sector collaboration on methane recovery and use initially in the areas of coal mining, oil and natural gas systems, and landfills, and subsequently in other areas as agreed to by the Partners.

- Develop improved emissions estimates and identify the largest relevant emission sources to facilitate project development.

- Identify cost-effective opportunities to recover methane emissions for energy production and potential financing mechanisms to encourage investment.

- Identify and address barriers to project development and improve the legal, regulatory, financial, institutional, technological and other conditions necessary to attract investment in methane recovery and utilization projects.

- Identify and implement collaborative projects aimed at addressing specific challenges to methane recovery, such as raising awareness in key industries, removing barriers to project development and implementation, identifying project opportunities, and demonstrating and deploying technologies. Partners will also work together to share lessons learned from these cooperative activities.

- Foster cooperation with the private sector, research organizations, development banks, and other relevant governmental and non-governmental organizations.

- Integrate and coordinate Partnership activities with related activities and initiatives.

- Support the identification and deployment of best management practices in the recovery and use of methane.

\footnotetext{
${ }^{29}$ This paragraph contributed by Rachel Goldstein, LMOP.
} 
- Work to improve scientific understanding and certainty in relation to the recovery and use of methane.

- Develop collaborative action plans that outline a series of concrete activities and actions that directly support the core goals and functions of the Partnership.

- Develop and implement a process for evaluating progress and reporting results.

These guidelines are taken from the Methane to Markets Partnership website. ${ }^{30}$

The goals of the partnership blend well with the initial objectives of CTP Korea and will help foster market transformation and in-country knowledge necessary for South Korea to continue to make progress in methane recovery activities.

${ }^{30} \mathrm{http}: / /$ www.methanetomarkets.org/about/terms.htm. 


\section{Lessons Learned}

\subsection{Key Factors}

A key factor in the success of LFG projects in Korea, and at Ulsan in particular, was the ability to attract and retain local Korean government officials' interest and commitment to methane recovery. Much of this responsibility fell on KEMCO and was facilitated by CTP Korea through holding in-country workshops and providing access to relevant information and technical expertise. SK Corporation was able to benefit greatly form CTP Korea activities. It had no prior experience in LFG projects but through KEMCO and some training provided by U.S. partners it was able to embrace the project and propel it to completion. For SK to be able to advance the project, however, Ulsan city officials needed to have an interest. KEMCO was responsible for initiating this interest in developing a LFG facility, as it would have been nearly impossible to conduct a project study, and carry the project through to completion without this initial awareness and interest.

Building awareness and interest were main factors of CTP Korea. KEMCO was the in-country 'champion' of LFG activity for South Korea and aggressively pursued awareness campaigns, provided basic assessments of potential landfill sites, oversaw the revolving fund for financing projects and held in-country conferences and workshops for training locals and networking internationally. KEMCO not only identified potential landfill sites, they looked over landfill data provided by the Ministry of Environment (MOE), created a list of the 15 sites that seemed to be the best candidates for LFG projects, contacted each site individually and followed-up with site visits and informational meetings to educate landfill operators and owners about LFG development.

KEMCO is funded by the Ministry of Commerce, Industry, and Energy (MOCIE). The South Korean government assigned responsibility for LFG awareness activities to both MOCIE and MOE. These two ministries, along with the local governments, are the main participants in LFG project work in South Korea. Each of their roles is significantly different, however, with MOCIE's work in the landfill [being] concentrated on the utilization of LFG while MOE's work is more related to the management of landfill sites. Local governments, on the other hand, own and operate the landfills and are the main audience for building awareness.

\subsection{Best Practices}

Several best practices can be derived from the Ulsan and Cheong ju case studies. These practices entail capacity building activities for creating the foundation of market transformation, the role of government in developing markets, the formation of strategic partnerships, and finding viable financing mechanisms. The following chart summarizes these 'best practices' and how each project approached the process. 


\begin{tabular}{|c|c|c|c|}
\hline Best Practices & $\begin{array}{l}\text { CTP Korea } \\
\text { involvement specific } \\
\text { to LFG projects }\end{array}$ & Ulsan & Cheong ju \\
\hline $\begin{array}{l}\text { Government assistance } \\
\text { in publicizing potential } \\
\text { projects }\end{array}$ & $\begin{array}{l}\text { MOCIE designated } \\
\text { KEMCO as the country } \\
\text { 'champion' of LFG } \\
\text { projects }\end{array}$ & $\begin{array}{l}\text { KEMCO approached } \\
\text { Ulsan City officials } \\
\text { regarding LFG projects } \\
\text { - these interactions } \\
\text { created the foundation } \\
\text { for pursuing the project }\end{array}$ & $\begin{array}{l}\text { KEMCO approached the } \\
\text { City of Cheong ju about } \\
\text { doing a landfill gas } \\
\text { project after identifying } \\
\text { the city's landfills as } \\
\text { prime candidates for } \\
\text { LFG recovery }\end{array}$ \\
\hline $\begin{array}{l}\text { Government assistance } \\
\text { with new developers and } \\
\text { providing forum for } \\
\text { trainings and building } \\
\text { awareness }\end{array}$ & $\begin{array}{l}\text { LFG workshops held in } \\
\text { South Korea and } \\
\text { funding for technical } \\
\text { assistance provided }\end{array}$ & $\begin{array}{l}\text { SK Corp formed a } \\
\text { relationship with } \\
\text { consultant in Denmark } \\
\text { after attending a } \\
\text { conference in Korea in } \\
\text { which both companies } \\
\text { participated }\end{array}$ & $\begin{array}{l}\text { KEMCO and EPA } \\
\text { LMOP funded } \\
\text { feasibility study }\end{array}$ \\
\hline $\begin{array}{l}\text { Revision of regulatory } \\
\text { framework/requirements }\end{array}$ & $\begin{array}{l}\text { Overhaul of solid waste } \\
\text { disposal and landfill } \\
\text { management practices }\end{array}$ & $\begin{array}{l}\text { Awareness increasing } \\
\text { among landfill operators } \\
\text { of environmental harms } \\
\text { due to increased } \\
\text { regulation }\end{array}$ & $\begin{array}{l}\text { Vents for LFG already } \\
\text { in place (due to } \\
\text { regulatory concerns) that } \\
\text { could be converted to } \\
\text { capture gas for LFG } \\
\text { recovery system }\end{array}$ \\
\hline Capacity building & $\begin{array}{l}\text { Pilot projects and } \\
\text { feasibility studies }\end{array}$ & $\begin{array}{l}\text { Ulsan facility } \\
\text { completed, successful } \\
\text { pilot project }\end{array}$ & $\begin{array}{l}\text { Feasibility study } \\
\text { completed; no project } \\
\text { development }\end{array}$ \\
\hline Financing Mechanisms & $\begin{array}{l}\text { KEMCO revolving fund } \\
\text { ERCs through the CDM }\end{array}$ & $\begin{array}{l}\text { Ulsan construction } \\
\text { financed through } \\
\text { revolving fund provided } \\
\text { by KEMCO }\end{array}$ & $\begin{array}{l}\text { ERCs at } \\
\text { U.S. } \$ 4.00 / \text { metric ton of } \\
\text { CO2 equivalent } \\
\text { projected to make LFG } \\
\text { recovery economical }\end{array}$ \\
\hline $\begin{array}{l}\text { Presence of in-country } \\
\text { agency focused on } \\
\text { implementation of } \\
\text { program/project }\end{array}$ & $\begin{array}{l}\text { KEMCO - } \\
\text { LFG 'Champion' } \\
\text { (MOCIE representative) } \\
\text { Environmental } \\
\text { Management Corp. } \\
\text { (EMC) (MOE } \\
\text { representative) }\end{array}$ & $\begin{array}{l}\text { KEMCO served as } \\
\text { strong in-country partner }\end{array}$ & $\begin{array}{l}\text { KEMCO approached } \\
\text { local government } \\
\text { officials directly and } \\
\text { able to reach out to } \\
\text { strategic partners }\end{array}$ \\
\hline
\end{tabular}

Figure 8: $\quad$ Best Practices of Ulsan and Cheong ju LFG projects 
KEMCO was designated by MOCIE as the lead in developing the needs assessment and technology teams for CTP Korea. KEMCO's overall objective is reducing barriers to energy efficiency through various methods including a dedicated fund that provides lowinterest loans. ${ }^{31}$ KEMCO was named as the central point of contact for coordinating CTP Korea activities and their strong commitment as an 'in-country' partner with NREL and the EPA on the Ulsan landfill development was a key component in the smoothness of the project's workings.

The phased approach that was suggested in the Cheong ju feasibility study can be taken away as a best practice for all LFG projects. This approach enables project managers to act on incoming data flows which provides a distinct advantage. By using the phased approach managers are able to make better decisions about the technical aspects of the project as well as being able to adjust more aptly to changing regulatory frameworks and other processes. In this way, projected landfill gas generation for various factors including baseline estimates, landfill gas recovery potential, and net annual methane emissions provided by feasibility studies act as stepping stones to build on and can be verified before greater capital costs are incurred. It is common practice in the U.S. to verify gas generation before proceeding any further on LFG projects and in this way "commercial utilization [occurs only after] the quantity and quality of LFG [is] verified." 32

\subsection{Common Barriers}

It is important to note that even when barriers are well documented and there are viable solutions available to overcome them - some projects will not prevail. Two identified barriers for LFG projects include shortages of qualified engineers in the methane recovery field and regulatory barriers to project implementation. The first barrier can be mitigated by finding qualified international partners as well as training in-country individuals, while addressing regulatory barriers often requires coordination between various government agencies.

Taking a closer look at the shortage of qualified engineers and the partnerships needed to address this barrier provides a revealing picture of the strategic partnership process. It is, of course, much easier to say a partnership needs to be formed than it is to actually create that partnership. This partnership can be further complicated by the nature of the relationship.

Initially when strategic partnerships were being discussed in regards to CTP Korea's program on energy service companies (ESCOs) the parties involved thought it would be best for ESCOs in Korea to partner with ESCOs in other countries to allow Korean companies to draw expertise and access to financing from the relationship. Through experience however, they found that this partnership may sometimes involve competing interests and that it is often best for Korean companies to form strategic partnerships with consulting firms that have similar qualities of expertise and access to financing as the ESCOs but no inadvertent

\footnotetext{
${ }^{31}$ Ulsan LFG 2 page summary, www.pi.energy.gov/pdf/library/EWSL/EWSLkorea.pdf.

${ }^{32}$ Feasibility Study, p. 16.
} 
conflict of interest. Even when this type of strategic partnership is formed, other considerations are imperative. These include ensuring that the philosophies of participant companies and their goals for the relationship be complementary and that the project is large enough to benefit the partners involved, but not so difficult as to overly stress a developing relationship. $^{33}$

These complex issues of strategic partnerships cannot be overstated, as all parties involved need to be committed to the project and willing to work through difficulties and differences to make sound decisions and needed compromises for the best possible result. For this to occur there must be a large amount of trust among partners as well as significant dedication to the project and overall mission. Developing a project from an idea to viable, working facility is a multi-stage process. With many agencies involved it only takes one party 'dropping the ball' at a certain stage to inhibit the completion of the project. Whether this is done inadvertently or intentionally, the result is the same.

A key consideration with landfill development in Korea is the overlapping yet separate authority between MOE, MOCIE, and local officials. This overlap can create an interdependency that requires coordination and consistent commitment to development by each institution. The traditional divisions between government agencies can create a barrier for some LFG projects. This is especially true in LFG development which has strong economic and environmental implications. The defined roles of MOCIE and MOE in regard to LFG projects illustrate this division. Each of the ministries approached the potential projects according to their own separate objectives, so there was no joint effort which may have strengthened arguments and incentives to get LFG development off the ground more quickly.

\footnotetext{
${ }^{33}$ Howard, D.L., "Republic of Korea Reduction of Financing Barriers for Energy Saving Performance Contracts.” NREL Technical Report NREL/TP-710-38630. November 2005.
} 


\section{Recommendations}

\subsection{Collaboration}

The Ulsan project is an example of the success of the CTP Korea LFG projects. The completion of the project and its subsequent success in operation fulfills the project activity objective of CTP. The strategic activity objective was also realized in the regulatory reforms and the effectiveness of KEMCO in identifying potential landfill sites and initiating development through collaboration and thoughtful review that will be an enabling factor for additional LFG projects to be completed.

The importance of collaboration cannot be overstated. There are many benefits to the collaborative process. As additional participants become involved, more support can be established, more expertise can be tapped, and stronger relationships are formed. There can also be negative side effects such as difficulty in aligning overall objectives, inability to reach a consensus and longer time frames required for deliberation and decision-making.

Looking to the future, it is important to capitalize on the positive aspects of collaboration while trying to minimize the negative issues. In creating programs to address complex energy issues careful collaboration will be needed due to the various groups involved. These groups all have diverse interests ranging from business and economic interests to health issues and environmental concerns. Each of these interests has legitimacy and needs to be addressed.

\subsection{Policy/Regulatory Changes}

The South Korean government has significantly changed the process by which solid waste is disposed. This is only an initial step in creating the environment and market for LFG utilization, but it is a very important one. Typical solid waste treatment methods in South Korea have included landfill dumping, sea dumping, incineration, and recycling. With the greater awareness of pollution hazards surrounding landfill dumping, some recent sites have been developed to operate using technologies to reduce the environmental pollution caused by landfill gas and leachate. Reclamation work has also been done on some expired landfill sites to minimize the effects of the pollution and prevent contamination of nearby environments. Most recently, on January 1, 2005, a law went into effect that prohibits the land filling of food waste. This is a major shift in solid waste management for Korea and shows a willingness to make needed changes to improve landfill management.

\subsection{Capacity Building}

Using LFG for energy is a win/win opportunity. Landfill gas utilization projects involve citizens, non-profit organizations, local governments, and industry in sustainable community planning and create partnerships. These projects go hand-in-hand with community and corporate commitments to cleaner air, renewable energy, economic development, improved public welfare and safety, and reductions in greenhouse gases. These objectives align well with those of CTP Korea which was designed to implement a few initial projects through local and international partnerships, which could then be used as examples 
to encourage and enable additional activity. Capacity building is also invaluable in the foundation of awareness and education that it provides which is necessary for market creation and penetration.

The 2005 conclusion of the CTP Korea project has left an opening that is being filled to some extent through U.S. EPA's LMOP and the M2M Partnership. Both of these programs have begun to play a larger role in LFG projects across South Korea. By linking communities with innovative ways to deal with landfill gas, LMOP contributes to the creation of livable communities that enjoy increased environmental protection, better waste management, and responsible community planning. ${ }^{34}$ The successful partnership involving the U.S. EPA LMOP program and KEMCO in providing the Cheong ju feasibility study is a good example of capacity building and illustrates LMOP's involvement with LFG projects in Korea.

Workshops and conferences were important aspects of capacity building facilitated by CTP Korea. South Korea has continued to participate in conferences regarding LFG which validates the value they have found in these activities. Providing a venue for the dissemination of knowledge and the formation of networks is a critical aspect in overcoming barriers and enabling the environment for market transformation. These workshops allowed the business community in South Korea to become familiar with their industry peers both nationally and internationally and also provided a forum for them to learn about various approaches to design, finance, and project planning.

\subsection{Future Direction}

To spur further development in LFG projects in South Korea an important factor will be finding ways to create economic feasibility for smaller landfill sites. $30-40 \%$ of landfills in Korea have a capacity of 500,000 - 1,000,000 million tons and have not been seriously considered for development because of their size. "EMC is researching technologies to make harnessing the LFG from these sites more cost effective." 35 If these sites can provide even a small portion of Korea's energy needs domestically they would be benefiting the country due to Korea's extensive reliance on imported fuels. Capturing the methane from these sites is an added benefit for its GHG mitigation factor which is likely to increase substantially as a motivator in years to come.

In 2004 during LFG outreach project meetings in Korea there was some discussion between KEMCO and EMC about joint work to further promote LFG projects in Korea. This type of collaboration could be promising in LFG outreach in order to maximize the efficacy of the overall mission. The collaboration needs to be carefully planned however, or the reverse effect will happen in which less is accomplished with more. One promising development is the formation of a LMOP-style program at EMC or KEMCO. The program does not directly involve MOCIE, but the two ministries have discussed coordination of activities involving landfills.

\footnotetext{
${ }^{34}$ www.epa.gov/lmop, Landfill Methane Outreach Program website.

${ }^{35}$ Chiu, Kong, Trip notes 2004.
} 
Perhaps steps can be taken to better align MOCIE's and MOE's efforts in promoting and supporting LFG projects in Korea. This partnering would be a promising endeavor which would strengthen each ministry's effectiveness by combining their resources in fulfilling South Korea's overall mission of "institutionally foster(ing) efficient energy use." ${ }^{36}$ It is becoming increasingly apparent in the energy sector that good business goes hand-in-hand with environmental stewardship. Combining MOCIE's strong industry connections and business background with MOE's strong environmental programs and regulatory function could create a framework in which the interest of both can be better served. This partnership at the ministry level would be beneficial in that it would apply a whole systems approach and therefore achieve a greater alignment of interests which would accelerate LFG utilization and GHG mitigation projects in South Korea.

\subsection{Conclusion}

As we look to tackle the tough questions of energy supply and climate change in the future there is much to learn from the past. The case studies of Ulsan and Cheong ju provide valuable information and insight in regards to landfill gas projects. Even though each new landfill gas project will have unique characteristics, the documentation of previous experience can serve as a guide that provides direction, tools, and inspiration to spur further development and encourage innovation.

LFG projects can provide energy while at the same time mitigating GHG emissions. This is an ideal solution in which more energy can be harnessed while less harm is done to the environment. The fact that LFG projects are also viable economically provides a strong foundation for these ventures. The challenge is in building effective networks of knowledge and relationships to complete projects successfully despite the various barriers that are often present.

\footnotetext{
${ }^{36}$ Energy Technology Policy in Korea, p. 2.
} 


\section{Bibliography}

Chan-su, Kang, "Garbage power gains fans as oil price soars," JoongAng Daily, (November 26, 2005). Available online -

http://joongangdaily.joins.com/200511/25/200511252204486009900090609062.html

Chiu, Kong, “Trip Report,” (June 2004, unpublished).

“CTP Program in Korea: Lessons Learned,” (2001?, unpublished).

“CTP Strategic Vision Outline," (January 2003, unpublished).

Energy Information Administration, "Comparison of Global Warming Potentials from the Second and Third Assessment Reports of the Intergovernmental Panel on Climate Change." Available online - http://www.eia.doe.gov/oiaf/1605/gwp.html

Ha, Gyung-Ae, Korea Energy Management Corporation, "Landfill Gas Project in South Korea," presentation at $5^{\text {th }}$ Annual LMOP Conference, (Washington DC - December 2001).

Ha, Gyung-Ae, Korea Energy Management Corporation, "Role of ESCOs in reducing GHG emission in Korea," workshop on Climate Change Issues, (Milan, Italy - December 2003).

Heil, Mark, “CTP Korea Landfill Gas Lessons Learned Paper - Draft Outline," (April 2005, unpublished).

Howard, Dave, “Foreign Travel Trip Report to Korea,” (August 2003, unpublished).

Howard, Dave, “Foreign Travel Trip Report to Korea,” (June 2004, unpublished).

Howard, D.L., "Republic of Korea Reduction of Financing Barriers for Energy Saving Performance Contracts." NREL Technical Report NREL/TP-710-38630. November 2005.

Korea Energy Economics Institute, Energy Information Korea. (Seoul 2004).

Ministry of Commerce, Industry, and Energy and R\&D Management Center for Energy Resources, "Energy Technology Policy in Korea," (1998).

Ministry of Environment, Republic of Korea, "Korea's Efforts to Reduce Climate Change and Methane Emissions," presentation at Methane to Markets Conference, (Buenos Aires, Brazil - November 2005). Available online http://www.methanetomarkets.org/events/2005/all/docs/presentations/steering/korea.pdf

NREL Korea projects, http://www.nrel.gov/environment/korea.html.

Schwengels, Paul, "U.S.-China CFC-Free Super-efficient Refrigerator Project," (October 2002). Available online -

http://www.usctcgateway.net/casestudies/CasestudiesDetail.cfm?LinkAdvID=64730 
SCS Engineers, DRAFT - "Feasibility Assessment Report for a Landfill Gas Utilization/Greenhouse Gas Mitigation Project at the Megalo Landfill, Cheong ju, South Korea," (April 2004).

TCAPP-Korea/WG2 (methane recovery from wastes and its utilization), "Concept paper on methane recovery from wastes for international cooperation," (April 2006?, unpublished).

“Three year plan for CTP Korea Activities,” (2002, unpublished).

Ulsan LFG 2 page summary, www.pi.energy.gov/pdf/library/EWSL/EWSLkorea.pdf.

U.S. EPA, "CTP Total Emissions Reductions,” (2004?, unpublished). (excel spreadsheet w/ landfill \& ESCO estimated reductions) 


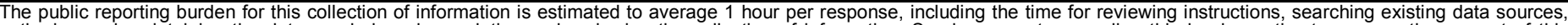

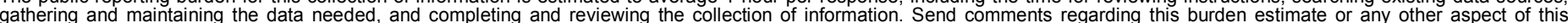

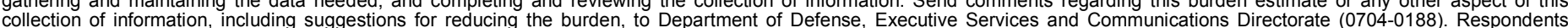

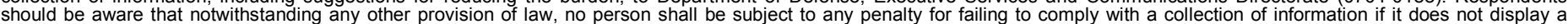

should be aware that notwithstanding

PLEASE DO NOT RETURN YOUR FORM TO THE ABOVE ORGANIZATION.

\begin{tabular}{l|l|l|l} 
1. REPORT DATE $(D D-M M-Y Y Y Y)$ & 2. & REPORT TYPE & 3. DATES COVERED (FrOm - TO)
\end{tabular}

December 2006

Technical Report

4. TITLE AND SUBTITLE

Case Studies from the Climate Technology Partnership: Landfill Gas

Projects in South Korea and Lessons Learned 5a. CONTRACT NUMBER

DE-AC36-99-G010337

5b. GRANT NUMBER

5c. PROGRAM ELEMENT NUMBER

5d. PROJECT NUMBER

NREL/TP-710-40428

5e. TASK NUMBER

WF98.2010

5f. WORK UNIT NUMBER
7. PERFORMING ORGANIZATION NAME(S) AND ADDRESS(ES)

National Renewable Energy Laboratory

1617 Cole Blvd.

Golden, CO 80401-3393
8. PERFORMING ORGANIZATION REPORT NUMBER

NREL/TP-710-40428

9. SPONSORING/MONITORING AGENCY NAME(S) AND ADDRESS(ES)

10. SPONSOR/MONITOR'S ACRONYM(S) NREL

11. SPONSORING/MONITORING AGENCY REPORT NUMBER

12. DISTRIBUTION AVAILABILITY STATEMENT

National Technical Information Service

U.S. Department of Commerce

5285 Port Royal Road

Springfield, VA 22161

13. SUPPLEMENTARY NOTES

14. ABSTRACT (Maximum 200 Words)

This paper examines landfill gas projects in South Korea. Two case studies provide concrete examples of lessons learned and offer practical guidance for future projects.

15. SUBJECT TERMS

Landfill gas; LFG; Korea; Ulsan; Cheong ju

\begin{tabular}{|c|c|c|}
\hline 6. SECURIT & CLASSIFICATI & N OF: \\
\hline $\begin{array}{l}\text { a. REPORT } \\
\text { Unclassified }\end{array}$ & $\begin{array}{l}\text { b. ABSTRACT } \\
\text { Unclassified }\end{array}$ & $\begin{array}{l}\text { c. THIS PAGE } \\
\text { Unclassified }\end{array}$ \\
\hline
\end{tabular}

\begin{tabular}{|c|c|}
\hline $\begin{array}{l}\text { 17. LIMITATION } \\
\text { OF ABSTRACT }\end{array}$ & $\begin{array}{l}\text { 18. NUMBER } \\
\text { OF PAGES }\end{array}$ \\
\hline UL & \\
\hline
\end{tabular}

19a. NAME OF RESPONSIBLE PERSON

19b. TELEPHONE NUMBER (Include area code) 